\title{
POPULATION DYNAMICS OF THE GREEN SHIELD SCALE, PULVINARIA PSIDII (HEMIPTERA : COCCIDAE) ON GUAVA TREES AT SHIBIN EL-QANATER DISTRICT, QALUBIYA GOVERNORATE, EGYPT
}

\author{
ELWAN, E. A., A. M. SERAG AND MAHA I. EL-SAYED \\ Plant Protection Research Institute, ARC, Dokki, Giza
}

(Manuscript received 5 January, 2011)

\begin{abstract}
The population dynamics of the green shield scale, Pulvinaria psidii (Mask.) (Hemiptera - Coccidae) was studied for two successive years (2008-2009) on guava trees at Shibin El-Qanater district, Qalubiya Governorate. The obtained results revealed that, $P$. psidii occurred on guava trees all the year round and has two overlapping generations a year. The $1^{\text {st }}$ generation started from early March to early August/mid-August, peaked in mid-May (early summer) with duration of $5.0-5.5$ months at field conditions of $20.7-21.3^{\circ} \mathrm{C}$ and $70.7-71.9 \%$ R.H. The $2^{\text {nd }}$ generation occurred from early May to mid-November, peaked in mid-August (late summer) with duration of $6.0-6.5$ months at $24.2-25.0^{\circ} \mathrm{C}$ and $69.4-$ $70.4 \%$ R.H., respectively. The favorable time for abundance of $P$. psidii occurred in early and late summer during both high temperature and relative humidity. The adult population was relatively higher than nymphal population one in winter months and this may be due to the cold weather and most of the nymphs attained to the adult stage which sheltered on stems bark or in the stem cracks.

Daily mean temperature and \%R.H. were effective on both nymph and adult populations in $1^{\text {st }}$ and $2^{\text {nd }}$ generations in the two studied years, the population was correlated with the increase of temperature. The combined effect of the daily mean temperature and \%R.H. on both nymph and adult populations was high on the both generations. The changes in the half monthly counts of nymph and adult populations referred to the effect of the tested weather factors on the $1^{\text {st }}$ generation ranged 83.8 $87.3 \% \& 55.8-75.9 \%$ and $55.7-69.1 \% \& 51.4-56.6 \%$ for the $2^{\text {nd }}$ generation in the two studied years, respectively.
\end{abstract}

\section{INTRODUCTION}

The green shield scale, Pulvinaria psidii (Mask.) (Hemiptera - Coccidae) has a wide range of host plants, it attacks fruit trees, ornamental plants and woody trees (Quayle, 1941, Hamon \& Williams, 1984) and occurs in many countries: India, Pakistan, Philippines (Reddy, 1965), Egypt (Salama \& Saleh, 1970, El-Minshawy et al, 1974 , Elwan, 2000, Shahein et al., 2004 and Radwan \& Hassan, 2009), Asia, Africa, Australia , Pacific Islands, North America, Central America, West India and South America (Anonymous, 1994). P. psidii consider as one of the main insect pests attack guava trees in Egypt, it causes severe damage to infested leaves and fruits by sucking the cell sap and excreting large amounts of honeydew that encourages the growth of sooty mould which blackens the leaves, decreases photosynthesis activity, and 
decreases vegetative growth of the infested trees. When the sooty mold occurs on fruit, it often becomes unmarketable or of a lower grade, because the fungus affects the appearance of the fruit and is difficult to wash off (Elmer and Brawner, 1975).

The present study was conducted to study the seasonal activity, duration and number of generations of $P$. psidii under the field conditions as well as the effect of daily means of air temperature and relative humidity on its activity to select an effective program for its control.

\section{MATERIALS AND METHODS}

The present work was carried out on guava (Psidium guajava) at Shibin ElQanater district, Qalubiya Governorate for two years extending from early January, 2008 until late December, 2009. The selected orchard received the normal agricultural practices without application any control measures before and during the period of study.

The seasonal abundance of the green shield scale, Pulvinaria psidii (Mask.) was carried out on four guava trees similar in size, age and vegetative growth. Regular half-monthly samples were picked up at random from the cardinal directions and the center core of each tree with rate of 25 leaves per tree. The collected samples were preserved in paper bags and transferred to the laboratory for inspection with stereoscopic-microscope and the insect population was counted and sorted to nymph and adults.

The meteorological data, mainly daily means of air temperature $\left({ }^{\circ} \mathrm{C}\right)$ and relative humidity (\%R.H.) was obtained from the Central Laboratory for Agricultural Meteorology, Agricultural Research Center, Ministry of Agriculture. The effect of the tested weather factors on the insect activity in the both studied years were statistically analyzed with MSTATC Program to determine the preferable time for the insect activity and the proper time for its control.

\section{RESULTS AND DISCUSSION}

\section{1- Seasonal abundance}

\section{A- The $1^{\text {st }}$ year}

\section{1- Nymphal population}

The obtained results (Fig.,1) showed that, the nymphal population in the $1^{\text {st }}$ year gradually decreased in January and February from 55 to 18.7 nymphs/leaf under field conditions at $12.8-14.2^{\circ} \mathrm{C}$ and $70.0-71.5 \%$ R.H. In March the nymphal population starts to increase and reached 24.4 nymphs/leaf by mid-March at $14.6^{\circ} \mathrm{C}$ and 74.5\%R.H. A continuous increase was observed in the nymphal population during 
April, where the population reached to 55.1 nymphs/leaf by mid-April at $16.9^{\circ} \mathrm{C}$ and $73 \%$ R.H.

In May, the population highly increased to reach the $1^{\text {st }}$ peak by mid-May (212.2 nymphs/leaf) at $20.3^{\circ} \mathrm{C}$ and $73 \%$ R.H., then the population decreased again during June (145.1- 141.7 nymphs/leaf). In July, the population gradually increased and reached the $2^{\text {nd }}$ peak by early August ( 432.5 nymphs/leaf) at environmental conditions of $27.5^{\circ} \mathrm{C}$ and $74 \%$ R.H. Gradual decrease was observed in the nymphal population during September and October whereas in November and December, the population greatly decreased to 60 nymphs/leaf by mid-December at $15.8^{\circ} \mathrm{C}$ and 69.3\%R.H.

\section{2- Adult population}

The seasonal abundance of the adult population (Fig., 1) has the same trend as the nymphal population. The population gradually decreased in January, February and mid-March from 87.0 to 36.9 adults/leaf under field conditions of $12.8-14.6^{\circ} \mathrm{C}$ and $70.0-74.5 \%$ R.H. Gradual increase was observed in the adult population during April and by mid-May, the population highly increased recording the $1^{\text {st }}$ peak $(107.7$ adults/leaf) at $20.3^{\circ} \mathrm{C}$ and $73.0 \%$ R.H.

The population decreased again during June (60.4 - 53.9 adults/leaf) whereas in July, the population highly increased and reached to the $2^{\text {nd }}$ peak by early August (212.3 adults/leaf) then decreased again during September from 75.1 to 56.1 adults/leaf. The adult population slowly increased during October, November and December (75.0-107 adults/leaf).
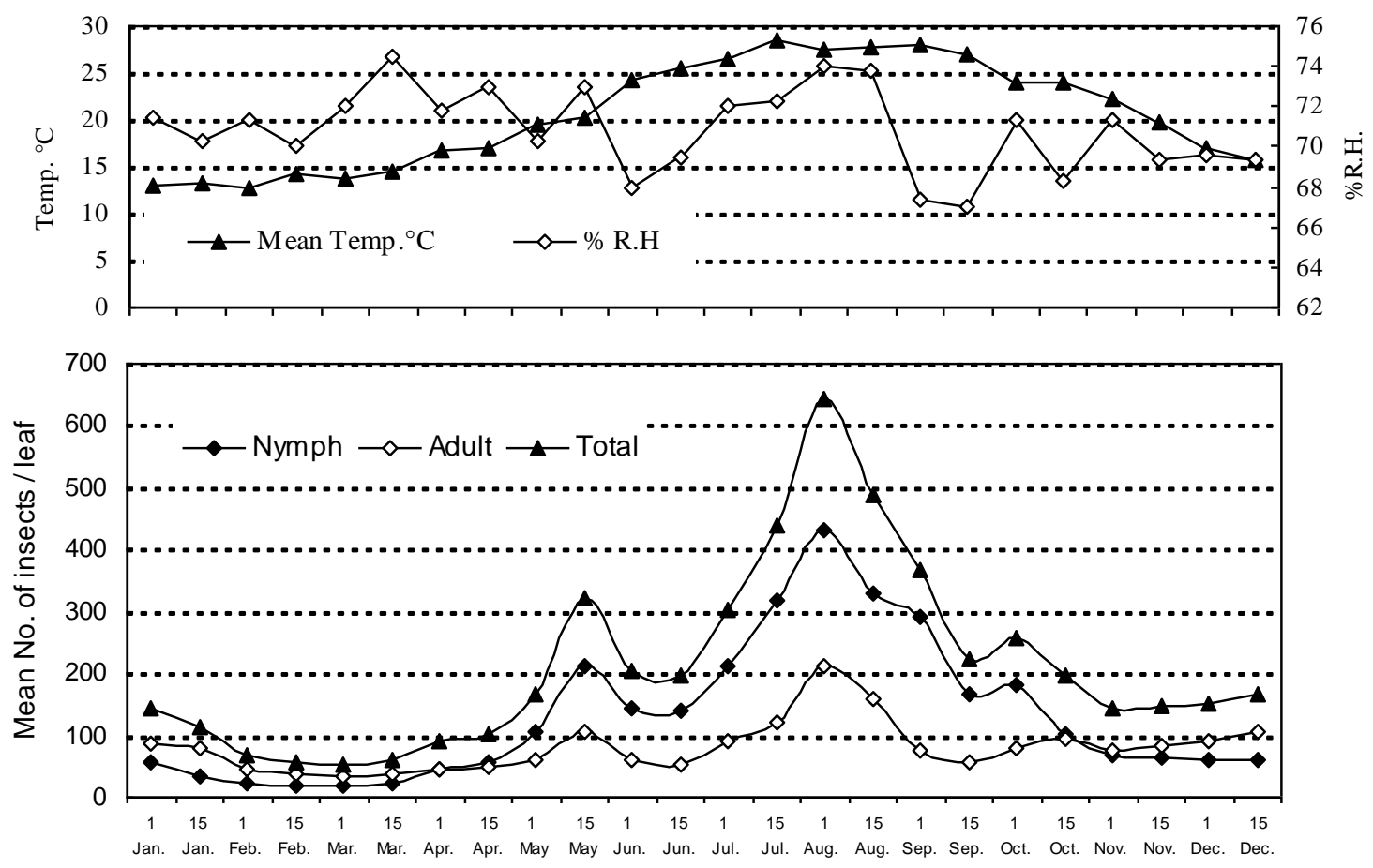
Fig. 1. Seasonal abundance of $P$. psidii on guava trees with corresponding halfmonthly means of temperature and \% R.H. at Shibin El-Qanater district, Qalubiya Governorate in the $1^{\text {st }}$ year (2008).

\section{B- The $2^{\text {nd }}$ year}

\section{1- Nymphal population}

In the $2^{\text {nd }}$ year (Fig., 2) the nymphal population gradually decreased during January, February and March (63.0 - 36.7 nymphs/leaf) at environmental conditions of $11.4-14.5^{\circ} \mathrm{C}$ and $67.8-72.8 \%$ R.H. In April, the population starts to increase gradually and highly increased during May recording the $1^{\text {st }}$ peak by mid-May (174.6 nymphs/leaf) at $21.9^{\circ} \mathrm{C}$ and $70.3 \%$ R.H. then the population decreased again during June (128.2 - 81.2 nymphs/leaf).

In July, the population gradually increased and reached to $2^{\text {nd }}$ peak by midAugust (382.3 nymphs/leaf) at environmental conditions of $26.2^{\circ} \mathrm{C}$ and $73.3 \%$ R.H. Gradual decrease was observed in the nymphal population during September and October (278.5 - 103.9 nymphs/leaf) whereas in November and December, the population greatly decreased and reached to 54.3 nymphs/leaf by mid-December at $16.8^{\circ} \mathrm{C}$ and $69.3 \%$ R.H.
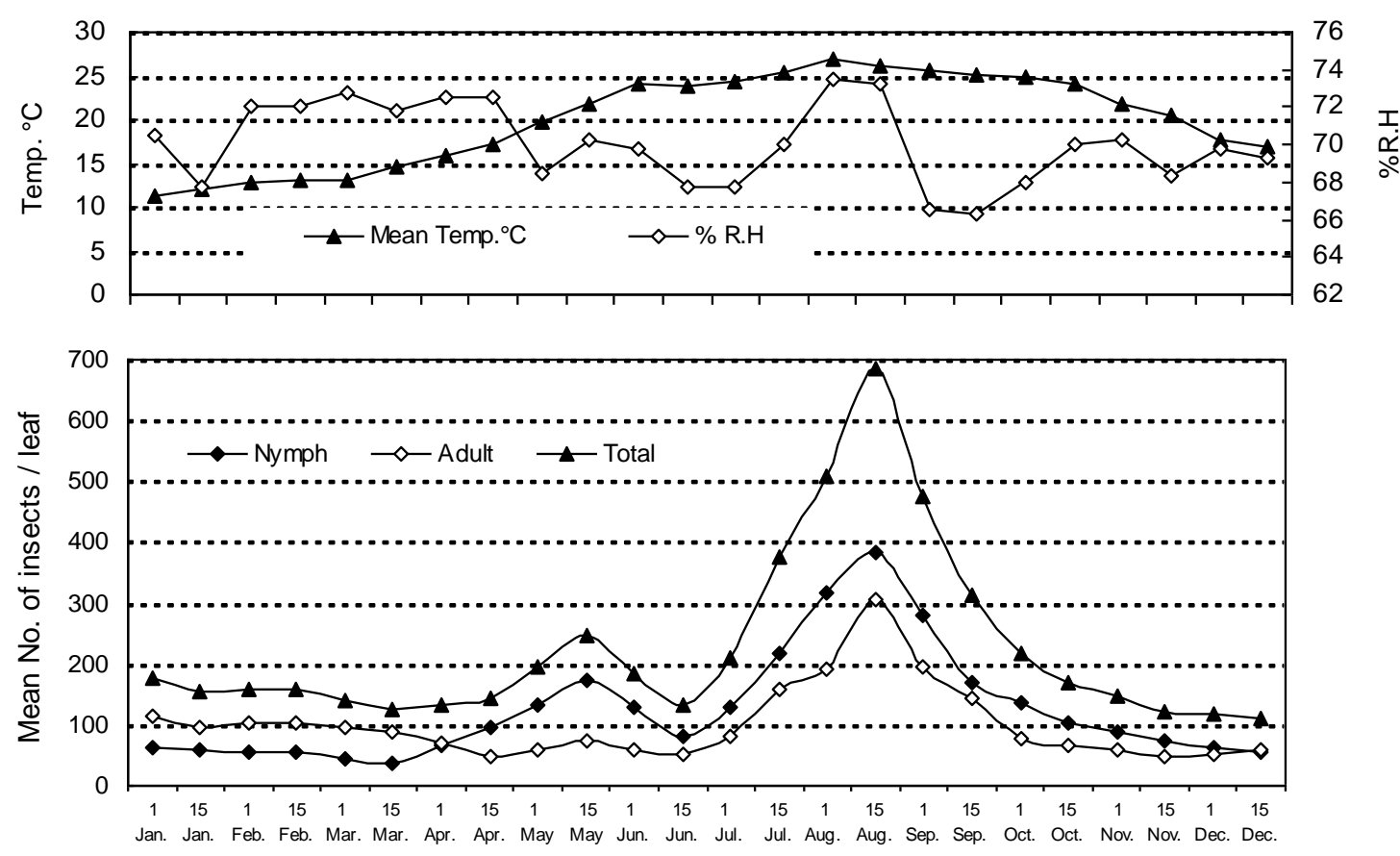

Fig. 2. Seasonal abundance of $P$. psidii on guava trees with corresponding halfmonthly means of temperature and \% R.H. at Shibin El-Qanater district, Qalubiya Governorate in the $2^{\text {nd }}$ year (2009). 


\section{2-Adult population}

The adult population (Fig., 2) has the same trend as the nymphal population. The population gradually decreased from January until mid-April (115.0 - 47.9 adults /leaf) under field conditions ranged $11.4-17.2^{\circ} \mathrm{C}$ and $67.8-72.5 \%$ R.H.

In early May, the population highly increased recording the $1^{\text {st }}$ peak in mid-May (74.1adults/leaf) at $21.9^{\circ} \mathrm{C}$ and $70.3 \%$ R.H. The population decreased again during June (57.6 - 52.7 adults/leaf) whereas in July, the population quickly increased recording $2^{\text {nd }}$ peak by mid-August (304.5 adults/leaf) at $26.2{ }^{\circ} \mathrm{C}$ and $73.3 \%$ R.H., then decrease occurred during September (195.1 - 144.0 adults/leaf). A continues decrease was observed in the adult population during November and December (58.0 - 48.8 adults/leaf).

The above-mentioned results revealed that, the green shield scale, P. psidii occurred on guava trees all the year round and abundant in mid-May and midAugust. So, the proper time for its abundance occurred in early and late summer during both temperature and \%R.H. were suitable. The adult population was relatively higher than the nymphal population in winter months and this may be referred to the cold weather and most of the nymphs attained to the adult stage which sheltered on stems bark or in the stem cracks.

\section{2- Number and duration of annual generations}

Data in Tables (1\&2) and Figs. (3) showed that, P. psidii has two overlapping generations a year under field conditions as follows:

\section{I- $\mathbf{1}^{\text {st }}$ Generation}

The $1^{\text {st }}$ generation started at the beginning of March in the both years and extended until early August in the $1^{\text {st }}$ year and mid-August in the $2^{\text {nd }}$ one. The duration of the $1^{\text {st }}$ generation lasted $5.0-5.5$ months at $20.7-21.3^{\circ} \mathrm{C}$ and $70.7-71.9$ $\%$ R.H in both years, respectively. The $1^{\text {st }}$ generation peaked in mid-May in the two years with total population ranged $217.8-234.8$ insects/leaf at $20.7-21.3^{\circ} \mathrm{C}$ and $70.7-71.9 \%$ R.H, respectively.

The generation density was relatively higher in the $1^{\text {st }}$ year than in the $2^{\text {nd }}$ one. In the $1^{\text {st }}$ year the generation density was 155.5 nymphs/leaf, 79.3 adults/leaf with total population of 234.8 insects/leaf at $21.3^{\circ} \mathrm{C}$ and $71.9 \%$ R.H. compared with 129.0 nymphs/leaf, 88.8 adults/leaf and total population of 217.8 insects/leaf at $20.7^{\circ} \mathrm{C}$ and $70.7 \%$ R.H. in the $2^{\text {nd }}$ year. 


\section{II- 2nd Generation}

The $2^{\text {nd }}$ generation started at early May in the both years and lasted to midNovember in the two years, respectively. The duration of the $2^{\text {nd }}$ generation lasted for 6.0 - 6.5 months under field conditions of $24.2-25.0^{\circ} \mathrm{C}$ and $69.4-70.4 \%$ R.H in both years. The $2^{\text {nd }}$ generation peaked in early August in the $1^{\text {st }}$ year and mid-August in the $2^{\text {nd }}$ one with total population ranged $296.9-304.0$ insects/leaf at $24.2-25.0^{\circ} \mathrm{C}$ and $69.4-70.4 \%$ R.H in both years, respectively.

The density of the $2^{\text {nd }}$ generation was relatively similar in the both years and higher than the $1^{\text {st }}$ generation. In the $1^{\text {st }}$ year the generation density was 208.2 nymphs/leaf, 95.8 adults/leaf with total population of 304.0 insects/leaf at $25.0^{\circ} \mathrm{C}$ and 70.4\% R.H. compared with 179.7 nymphs/leaf, 117.2 adults/leaf and total population of 296.9 insects/leaf at $24.2^{\circ} \mathrm{C}$ and $69.3 \%$ R.H. in the $2^{\text {nd }}$ year.

Table 1. Number and duration of annual generations of $P$. psidii on guava trees at Shibin El-Qanater district, Qalubiya Governorate in the $1^{\text {st }}$ year $(2008)$

\begin{tabular}{|c|c|c|c|c|c|c|c|c|c|}
\hline \multirow[b]{2}{*}{ Generation } & \multirow{2}{*}{$\begin{array}{l}\text { Insect } \\
\text { stage }\end{array}$} & \multicolumn{3}{|c|}{ Generation period } & \multicolumn{3}{|c|}{ Generation size } & \multirow{2}{*}{$\begin{array}{l}\text { Mean } \\
{ }^{\circ} \mathrm{C}\end{array}$} & \multirow{2}{*}{$\begin{array}{l}\text { R.H } \\
\%\end{array}$} \\
\hline & & From & To & $\begin{array}{l}\text { Duration } \\
\text { / month }\end{array}$ & $\begin{array}{c}\text { Nymphs } \\
\text { /leaf }\end{array}$ & $\begin{array}{c}\text { Adults } \\
\text { /leaf }\end{array}$ & $\begin{array}{c}\text { Total } \\
\text { population }\end{array}$ & & \\
\hline \multirow{2}{*}{$\begin{array}{c}1^{\text {st }} \\
\text { Generation } \\
\end{array}$} & Nymph & $1^{\text {st }}$ Mar. & $1^{\text {st }}$ Aug. & \multirow{2}{*}{5} & \multirow{2}{*}{155.5} & \multirow{2}{*}{79.3} & \multirow{2}{*}{234.8} & \multirow{2}{*}{21.3} & \multirow{2}{*}{71.9} \\
\hline & Adult & $1^{\text {st }}$ Mar. & $1^{\text {st }}$ Aug. & & & & & & \\
\hline \multirow{2}{*}{$2^{\text {nd }}$} & Nymph & $1^{\text {st }}$ May & $1^{\text {st }}$ Nov. & \multirow{2}{*}{6} & \multirow{2}{*}{208.2} & \multirow{2}{*}{95.8} & \multirow{2}{*}{304.0} & \multirow{2}{*}{25.0} & \multirow{2}{*}{70.4} \\
\hline & Adult & $1^{\text {st }}$ May & $1^{\text {st }}$ Nov. & & & & & & \\
\hline
\end{tabular}

Table 2. Number and duration of annual generations of $P$. psidii on guava trees at Shibin El-Qanater district, Qalubiya Governorate in the $2^{\text {nd }}$ year (2009).

\begin{tabular}{|c|c|c|c|c|c|c|c|c|c|}
\hline \multirow[b]{2}{*}{ Generation } & \multirow{2}{*}{$\begin{array}{l}\text { Insect } \\
\text { stage }\end{array}$} & \multicolumn{3}{|c|}{ Generation period } & \multicolumn{3}{|c|}{ Generation size } & \multirow{2}{*}{$\begin{array}{c}\text { Mean } \\
{ }^{\circ} \mathrm{C}\end{array}$} & \multirow{2}{*}{$\begin{array}{r}\text { R.H } \\
\%\end{array}$} \\
\hline & & From & To & $\begin{array}{l}\text { Duration } \\
\text { / month }\end{array}$ & $\begin{array}{c}\text { Nymphs } \\
\text { /leaf }\end{array}$ & $\begin{array}{l}\text { Adults } \\
\text { /leaf }\end{array}$ & $\begin{array}{c}\text { Total } \\
\text { population }\end{array}$ & & \\
\hline \multirow{2}{*}{$\begin{array}{c}1^{\text {st }} \\
\text { Generation } \\
\end{array}$} & Nymph & $1^{\text {st }}$ Mar. & Mid-Aug. & \multirow{2}{*}{5.5} & \multirow{2}{*}{129.0} & \multirow{2}{*}{88.8} & \multirow{2}{*}{217.8} & \multirow{2}{*}{20.7} & \multirow{2}{*}{70.7} \\
\hline & Adult & $1^{\text {st }}$ Mar. & Mid-Aug. & & & & & & \\
\hline \multirow{2}{*}{$\begin{array}{c}2^{\text {nd }} \\
\text { Generation }\end{array}$} & Nymph & $1^{\text {st }}$ May & Mid-Nov. & \multirow{2}{*}{6.5} & \multirow{2}{*}{179.7} & \multirow{2}{*}{117.2} & \multirow{2}{*}{296.9} & \multirow[b]{2}{*}{24.2} & \multirow{2}{*}{69.4} \\
\hline & Adult & $1^{\text {st }}$ May & Mid-Nov. & & & & & & \\
\hline
\end{tabular}




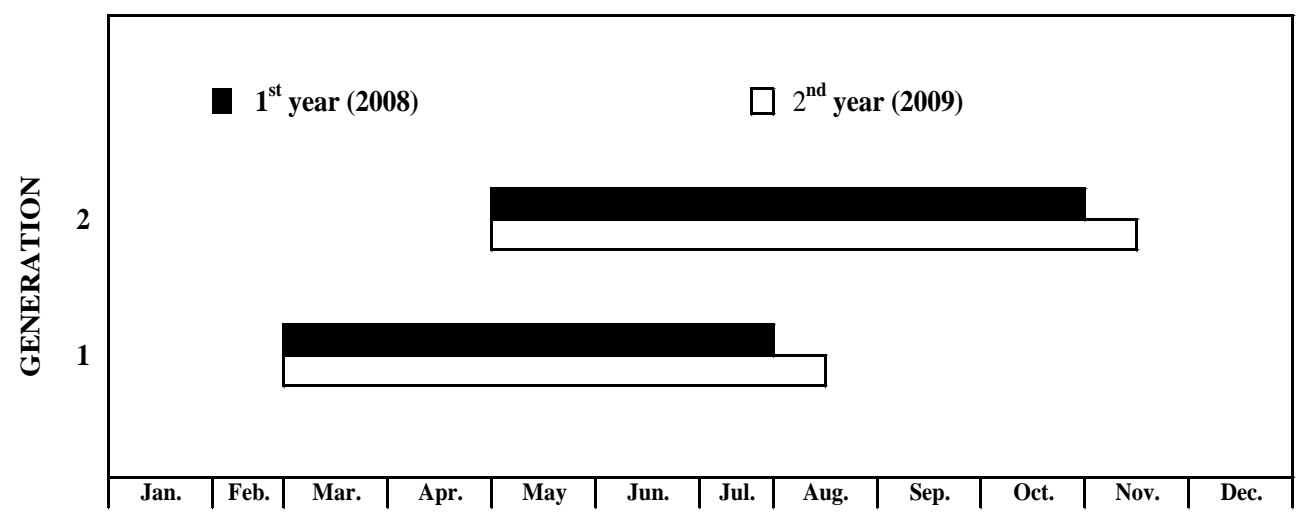

Fig. 3. Number and duration of annual generations of $P$. psidii on guava trees at Shibin El-Qanater district, Qalubiya Governorate in the both years (2008 \& 2009).

The afore-mentioned results showed that, $P$. psidii has two overlapping generations per year, the $1^{\text {st }}$ generation started from early March to early August/midAugust, peaked in mid-May (early summer) with duration of $5.0-5.5$ months at field conditions ranged $20.7-21.3^{\circ} \mathrm{C}$ and $70.7-71.9 \%$ R.H. whereas the $2^{\text {nd }}$ generation occurred from early May to mid-November peaked in mid-August (late summer) with duration of $6.5-6.5$ months under environmental conditions ranged $24.2-25.0^{\circ} \mathrm{C}$ and $69.4-70.4 \%$ R.H., respectively.

The obtained results in agreement with Salama and Saleh (1970) they revealed that, $P$. psidii passes through two annual generations on guava trees in Alexandria district and has a high peak of seasonal abundance in August. El-Minshawy et al. (1974) showed that, P. psidii has two generations per annum on guava trees in Alexandria, the $1^{\text {st }}$ generation begins in October and ends in April whereas the $2^{\text {nd }}$ one begins in late May and lasted to October.

Hendawy (1999) showed that P. psidii has two peaks on guava trees in Kafr ElSheikh Governorate, the $1^{\text {st }}$ peak appeared at the beginning of November whereas the $2^{\text {nd }}$ one appeared in the beginning of August. Shahein, et al. (2004) indicated that, $P$. psidii has two generations annually in inner or outer zones of the guava trees in Sharkia Governorate, the $1^{\text {st }}$ generation occurred from the beginning of January till the end of June, while the $2^{\text {nd }}$ one founded from the beginning of July till the end of December.

On the other hand, Chloropulvinaria psidii has three overlapping generations a year on mango trees occurred in spring, summer and autumn in Qalubiya Governorate (Elwan, 2000). On the ornamental plants, Chloropulvinaria psidii has three overlapping broods per season on the rice paper, Aralia papyrifera at the Botanic Garden at ElQanatir El- Khairiya, Qalubiya Governorate. The $1^{\text {st }}$ brood appeared from mid-March to 
the end of July and the $2^{\text {nd }}$ brood from August until later October whereas the $3^{\text {rd }}$ brood took place from the beginning of November and continued until the beginning March (El-Borollosy et al., 1990).

Moursi et al. (2003) showed that, the seasonal abundance of Chloropulvinaria psidii was varied on four ornamental plants (Ficus benghallensis, F. nitida, Pittsporum tobira and Schinus terebinthifolius) cultivated at public gardens (Shallalat, Antoniadis and Montazaha) in Alexandria governorate. The infestation reached its maximum rate during November on Ficus nitida in Shallalate and Antoniadis gardens and during July in Montazaha whereas on $F$. benghallensis, the insect recorded three peaks of abundance during June, August and January. On Schinus terebinthifolius, the insect reached its maximum rate of infestation from September until February in Shallalat garden while in Montazaha garden, the insect was observed as a main pest on $P$. tobira with highest rate of infestation during June and July. On mulberry trees, $P$. psidii has two main periods of seasonal activity occurred in autumn (one generation) and summer (two generation) in Qalubiya Governorate (Radwan \& Hassan, 2009).

\section{4- Effect of main weather factors on the annual generations}

\section{I- The $1^{\text {st }}$ generation}

\section{A: Nymphal population}

\section{1-Effect of daily mean temperature}

Data in Tables (3\&4) showed positive relation, highly significant ( $r=0.849$ \& 0.786 ) for the daily mean temperature on the nymphal activity during the $1^{\text {st }}$ generation in the both studied years. The real effect of this factor on the nymphal activity in the $1^{\text {st }}$ generation appeared from the partial regression value which was highly significant in the both years ( $\mathrm{t}$ value $=7.3 \& 6.4$ ) when the daily mean relative humidity become around its mean. The obtained results revealed that, daily mean temperature was under the optimum range of the nymphal activity in the $1^{\text {st }}$ generation during both studied years, respectively.

\section{2- Effect of daily mean relative humidity}

Daily mean relative humidity (Tables, $3 \& 4$ ) showed positive relation and insignificant $(r=0.164 \& 0.071)$ on the nymphal population in the $1^{\text {st }}$ generation in the two years. The real effect of this factor on the nymphal activity appeared from the partial regression value which was significant in the both years ( $\mathrm{t}$ value $=3.1 \& 3.3$ ) when the daily mean temperature become around its mean. The obtained results revealed that, daily mean relative humidity was under the optimum range of the nymphal activity in the $1^{\text {st }}$ generation in the both years, respectively. 


\section{3- The combined effect of the daily mean temperature and relative humidity}

The combined effect (Tables, $3 \& 4$ ) of both daily mean temperature and relative humidity were highly significant $(F=27.5 \& 20.8)$ on the nymphal population in the $1^{\text {st }}$ generation in the two years. The changes in the half monthly counts of the nymphal population referred to the effect of the tested weather factors ranged $83.8-87.3 \%$ in both years, respectively.

\section{B: Adult population}

\section{1-Effect of daily mean temperature}

Daily mean temperature (Tables, $3 \& 4$ ) showed positive relation on the adult activity in the $1^{\text {st }}$ generation, significant in the $1^{\text {st }}$ year and insignificant in the $2^{\text {nd }}$ one $(r=0.688 \& 0.400)$, respectively. The exact effect of this factor on the adult activity was highly significant in the $1^{\text {st }}$ year $(t$ value $=4.6)$ and significant in the $2^{\text {nd }}$ one $(t=2.7)$ when the daily mean relative humidity become around its mean. The obtained results revealed that, daily mean temperature was under the optimum range of the adult activity in both years, respectively.

Table 3. Effect of daily mean temperature and \%R.H. on $P$. psidii generations on guava trees at Shibin El-Qanater district, Qalubiya Governorate in the $1^{\text {st }}$ year (2008).

\begin{tabular}{|c|c|c|c|c|c|c|c|c|c|c|c|}
\hline \multirow{2}{*}{ 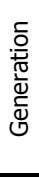 } & \multirow{2}{*}{$\begin{array}{l}\text { Insect } \\
\text { stage }\end{array}$} & \multicolumn{2}{|c|}{$\begin{array}{c}\text { Generation } \\
\text { duration }\end{array}$} & \multirow{2}{*}{$\begin{array}{c}\text { Generation } \\
\text { Duration } \\
\text { / month }\end{array}$} & \multicolumn{2}{|c|}{ Weather factors } & \multirow{2}{*}{$\begin{array}{c}\begin{array}{c}\text { Simple } \\
\text { Correlation }\end{array} \\
r \\
\text { Value } \\
\end{array}$} & \multicolumn{2}{|c|}{$\begin{array}{c}\text { Multi-regression } \\
\text { values }\end{array}$} & \multicolumn{2}{|c|}{$\begin{array}{l}\text { ANOVA } \\
\text { Table }\end{array}$} \\
\hline & & From & To & & Factor & Mean & & $\begin{array}{l}* \text { p. reg. } \\
\pm \text { s.e }\end{array}$ & $\begin{array}{c}\mathrm{t} \\
\text { value }\end{array}$ & $\begin{array}{c}\mathrm{F} \\
\text { value }\end{array}$ & $\begin{array}{c}\text { E.V. } \\
\%\end{array}$ \\
\hline \multirow{2}{*}{ 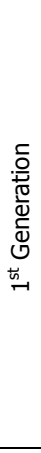 } & Nymph & $\begin{array}{l}1 \text { st } \\
\text { Mar. }\end{array}$ & $\begin{array}{l}\text { 1st } \\
\text { Aug. }\end{array}$ & 5 & $\begin{array}{c}\text { Mean } \\
\text { temp. } \\
\text { Mean } \\
\text { \%R.H. }\end{array}$ & $21.3^{\circ} \mathrm{C}$ & $\begin{array}{c}0.849 * * \\
0.164\end{array}$ & $23.0 \pm 3.2$ & $\begin{array}{l}7.3^{* *} \\
3.1^{*}\end{array}$ & $27.5 * *$ & 87.3 \\
\hline & Adult & $\begin{array}{l}\text { 1st } \\
\text { Mar. }\end{array}$ & $\begin{array}{l}\text { 1st } \\
\text { Aug. }\end{array}$ & 5 & $\begin{array}{c}\text { Mean } \\
\text { temp. } \\
\text { Mean } \\
\text { \%R.H. }\end{array}$ & $21.3^{\circ} \mathrm{C}$ & $\begin{array}{l}0.688^{*} \\
0.344\end{array}$ & $8.1 \pm 1.8$ & $\begin{array}{l}4.6 * * \\
3.1^{*}\end{array}$ & $12.6 * *$ & 75.9 \\
\hline \multirow{4}{*}{ 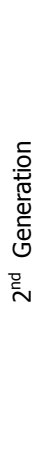 } & \multirow[t]{2}{*}{ Nymph } & \multirow{2}{*}{$\begin{array}{l}\text { 1st } \\
\text { May }\end{array}$} & \multirow{2}{*}{$\begin{array}{l}1 \text { st } \\
\text { Nov. }\end{array}$} & \multirow[t]{2}{*}{6} & $\begin{array}{c}\text { Mean } \\
\text { temp. } \\
C\end{array}$ & $25.0^{\circ} \mathrm{C}$ & $0.667^{*}$ & $24.6 \pm 6.4$ & $3.9 * *$ & \multirow[t]{2}{*}{$11.2^{* *}$} & \multirow[t]{2}{*}{69.1} \\
\hline & & & & & $\begin{array}{l}\text { Mean } \\
\text { \%R.H. }\end{array}$ & $70.4 \%$ & 0.464 & $17.7 \pm 6.3$ & $2.8^{*}$ & & \\
\hline & \multirow[t]{2}{*}{ Adult } & \multirow{2}{*}{$\begin{array}{l}\text { 1st } \\
\text { May }\end{array}$} & \multirow{2}{*}{$\begin{array}{l}1 \text { st } \\
\text { Nov. }\end{array}$} & \multirow[t]{2}{*}{6} & $\begin{array}{c}\text { Mean } \\
\text { temp. } \\
\text { C }\end{array}$ & $25.0^{\circ} \mathrm{C}$ & 0.384 & $6.2 \pm 3.5$ & 1.8 & \multirow[t]{2}{*}{$5.3^{*}$} & \multirow[t]{2}{*}{51.4} \\
\hline & & & & & $\begin{array}{l}\text { Mean } \\
\text { \%R.H. }\end{array}$ & $70.4 \%$ & $0.598^{*}$ & $9.3 \pm 3.4$ & $2.8^{*}$ & & \\
\hline
\end{tabular}

*P. reg. = Partial regression coefficient 
Table 4. Effect of daily mean temperature and \%R.H. on P. psidii generations on guava trees at Shibin El-Qanater district, Qalubiya Governorate in the $2^{\text {nd }}$ year (2009).

\begin{tabular}{|c|c|c|c|c|c|c|c|c|c|c|c|}
\hline \multirow{2}{*}{ 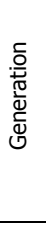 } & \multirow{2}{*}{$\begin{array}{l}\text { Insect } \\
\text { stage }\end{array}$} & \multicolumn{2}{|c|}{$\begin{array}{c}\text { Generation } \\
\text { duration } \\
\end{array}$} & \multirow{2}{*}{$\begin{array}{l}\text { Generation } \\
\text { Duration } \\
\text { / month }\end{array}$} & \multicolumn{2}{|c|}{ Weather factors } & \multirow{2}{*}{$\begin{array}{c}\text { Simple } \\
\text { correlation } \\
r \\
\text { value }\end{array}$} & \multicolumn{2}{|c|}{$\begin{array}{c}\text { Multi-regression } \\
\text { values }\end{array}$} & \multicolumn{2}{|c|}{$\begin{array}{l}\text { ANOVA } \\
\text { Table }\end{array}$} \\
\hline & & From & To & & Factor & Mean & & $\begin{array}{l}\text { P. reg. * } \\
\pm \text { s.e }\end{array}$ & $\begin{array}{c}\mathrm{t} \\
\text { value } \\
\end{array}$ & $\begin{array}{c}\mathrm{F} \\
\text { value } \\
\end{array}$ & $\begin{array}{l}\text { E.V. } \\
\% \\
\end{array}$ \\
\hline \multirow{2}{*}{ 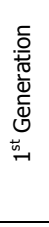 } & Nymph & $1^{\text {st }}$ Mar. & Mid-Aug. & 5.5 & $\begin{array}{l}\text { Mean temp. C } \\
\text { Mean \%R.H. }\end{array}$ & $\begin{array}{l}20.7^{\circ} \mathrm{C} \\
70.7 \% \\
\end{array}$ & $\begin{array}{c}0.786 * * \\
0.071 \\
\end{array}$ & $\begin{array}{l}17.8 \pm 2.8 \\
20.8 \pm 6.3 \\
\end{array}$ & $\begin{array}{c}6.4 * * \\
3.3^{*} \\
\end{array}$ & $20.8^{* *}$ & 83.8 \\
\hline & Adult & $1^{\text {st }}$ Mar. & Mid-Aug. & 5.5 & $\begin{array}{l}\text { Mean temp. C } \\
\text { Mean \%R.H. }\end{array}$ & $\begin{array}{l}20.7^{\circ} \mathrm{C} \\
70.7 \% \\
\end{array}$ & 0.388 & $\begin{array}{l}6.9 \pm 2.5 \\
15.6 \pm 5.8\end{array}$ & $\begin{array}{c}2.7 * \\
2.7 * \\
\end{array}$ & $5.1^{*}$ & 55.8 \\
\hline \multirow{2}{*}{ 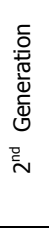 } & Nymph & $1^{\text {st }}$ May & Mid-Nov. & 6.5 & $\begin{array}{l}\text { Mean temp.C } \\
\text { Mean \%R.H. }\end{array}$ & $24.2^{\circ} \mathrm{C}$ & 0.629* & $25.9 \pm 10.2$ & $2.5^{*}$ & $6.3^{*}$ & 55.7 \\
\hline & Adult & $1^{\text {st }}$ May & Mid-Nov. & 6.5 & $\begin{array}{l}\text { Mean temp. C } \\
\text { Mean \%R.H. }\end{array}$ & $\begin{array}{l}24.2^{\circ} \mathrm{C} \\
69.4 \% \\
\end{array}$ & 0.696* & $24.9 \pm 8.3$ & 3.0* & $6.5^{*}$ & 56.6 \\
\hline
\end{tabular}

*P. reg. $=$ Partial regression coefficient

\section{2- Effect of daily mean relative humidity}

Daily mean relative humidity (Tables, 3\&4) was positive and insignificant ( $r$ $=0.344 \& 0.388$ ) on the adult population in the both studied years. This factor showed significant effect on the adult activity in the both years ( $t$ value $=3.1 \& 2.7$ ) when daily mean temperature become around its mean. The obtained results revealed that, daily mean relative humidity was under the optimum range of the adult activity in the $1^{\text {st }}$ generation in the both years, respectively.

\section{3-The combined effect of the daily mean temperature and relative}

\section{humidity}

The combined effect (Tables, 3\&4) of both daily mean temperature and relative humidity on the adult activity in the $1^{\text {st }}$ generation was highly significant in the $1^{\text {st }}$ year $(F=12.6)$ and significant in the $2^{\text {nd }}$ one $(F=5.1)$. The changes in the half monthly counts of the adult population referred to the effect of the two tested weather factors ranged $55.8-75.9 \%$, in the two years, respectively.

\section{II- The $2^{\text {nd }}$ generation}

\section{A: Nymphal population}

\section{1- Effect of daily mean temperature}

Daily mean temperature (Tables, 3\&4) showed significant positive relation ( $r$ $=0.667 \& 0.629$ ) on the nymphal activity during the $2^{\text {nd }}$ generation in the both years. The effect of this factor on the nymphal activity in the $2^{\text {nd }}$ generation was highly 
significant in the $1^{\text {st }}$ year $(t$ value $=3.9)$ and significant in the $2^{\text {nd }}$ year one $(t$ value $=$ 2.5) when the daily mean relative humidity become around its mean. The obtained results revealed that, daily mean temperature was under the optimum range of nymphal activity in the $2^{\text {nd }}$ generation in the both years, respectively.

\section{2- Effect of daily mean relative humidity}

Daily mean relative humidity (Tables, $3 \& 4$ ) showed positive relation on the nymphal population in the $2^{\text {nd }}$ generation, insignificant in the $1^{\text {st }}$ year $(r=0.464)$ and significant in the $2^{\text {nd }}$ one $(r=0.522)$. The effect of this factor on the nymphal activity was significant in the $1^{\text {st }}$ year ( $t$ value $=2.8$ ) and insignificant effect in the $2^{\text {nd }}$ one ( $t$ value $=1.9$ ) when the daily mean temperature become around its mean. The obtained results revealed that, daily mean relative humidity was under the optimum range of the nymphal activity in the $1^{\text {st }}$ year and within the optimum range in the $2^{\text {nd }}$ one, respectively.

\section{3-The combined effect of the daily mean temperature and relative humidity}

The combined effect (Tables, 3\&4) of both daily mean temperature and relative humidity was highly significant on the nymphal population in the $1^{\text {st }}$ year $(F=11.2)$ and significant in the $2^{\text {nd }}$ one $(F=6.3)$, respectively. The changes in the half monthly counts of the nymphal population referred to the effect of the tested weather factors ranged 55.7- $69.1 \%$ in both years, respectively.

\section{B: Adult population}

\section{1-Effect of daily mean temperature}

Daily mean temperature (Tables, 3\&4) showed positive relation on the adult activity in the $2^{\text {nd }}$ generation, insignificant in the $1^{\text {st }}$ year and significant in the $2^{\text {nd }}$ one ( $r=0.384 \& 0.696)$, respectively. The effect of this factor on the adult activity in the $2^{\text {nd }}$ generation was insignificant in the $1^{\text {st }}$ year ( $t$ value $=1.8$ ) and significant in the $2^{\text {nd }}$ one ( $t$ value $=3.0$ ) when the daily mean relative humidity become around its mean. The obtained results revealed that, daily mean temperature within the optimum range of the adult activity in the $2^{\text {nd }}$ generation in the $1^{\text {st }}$ year and under the optimum range in the $2^{\text {nd }}$ one, respectively.

\section{2- Effect of daily mean relative humidity}

Data in Tables (3\&4) showed that, daily mean relative humidity was positive, significant $(r=0.598)$ on the adult population in the $1^{\text {st }}$ year and insignificant in the $2^{\text {nd }}$ one $(r=0.422)$. This factor showed significant effect on the adult activity in the $1^{\text {st }}$ year ( $t$ value $=2.8$ ) and insignificant in the $2^{\text {nd }}$ year $(t=1.4)$ when the daily mean temperature become around its mean. The obtained results revealed that, daily mean 
relative humidity was under the optimum range of adult activity in the $2^{\text {nd }}$ generation in the $1^{\text {st }}$ year and within the optimum range in the $2^{\text {nd }}$ year, respectively.

\section{3-The combined effect of the daily mean temperature and relative humidity}

The combined effect (Tables, 3\&4) of both daily mean temperature and relative humidity on the adult activity was significant $(F=5.3 \& 6.5)$ in the $2^{\text {nd }}$ generation in the two years, respectively. The changes in the half monthly counts of the adult population referred to the effect of the two tested weather factors showing $51.4 \%$ and $56.6 \%$ for both years, respectively.

The present results proved that, daily mean temperature and relative humidity were effective on both nymph and adult populations in the two generations in both studied years and the population increase with increase of temperature. The changes in the half monthly counts of nymph and adult populations referred to the effect of the tested weather factors ranged $83.8-87.3 \% \& 55.8-75.9 \%$ in the $1^{\text {st }}$ generation and $55.7-69.1 \% \& 51.4 \%-56.6 \%$ in $2^{\text {nd }}$ generation, respectively.

\section{REFERENCES}

1- Anonymous.1994. International Institute of Entomology. Distribution Maps of Pests No. 59 ( $1^{\text {st }}$ rev. $), 56$ Queen's Gate, London, Sw7, 5IR, UK.

2- El-Borollosy, F. M. , M. M. El-Bolok , A. I. Ezz and Shadia M. Assem .1990. Ecological studies on the soft scale insect, Chloropulvinaria psidii (Maskell) (Coccidae - Homoptera) on the rice paper ornamental plant, Aralia papyrifera (Hook) (Aralliaceae). Bull. Soc. ent. Egypte, 69:267-275.

3- Elmer, H. S. and O. L. Brawner . 1975. Control of Brown Soft Scale in Central Valley. Citrograph. 60(11): 402-403.

4- El-Minshawy, A. M., S. M. Hammad and K. S. Moursi.1974. Seasonal abundance of the scale insects and mealy bugs attacking guava trees in Alexandria district. $2^{\text {nd }}$ Egypt. Pest Cont. Cong. Alexandria: 571-586.

5- Elwan, A. E. 2000. Ecological studies on the green shield scale, Chloropulvinaria psidii (Mask.) (Homoptera - Coccoidea - Coccidae) on mango trees, Qalubiya Governorate, Egypt. Egypt. J. Appl. Sci., 15(7): 603-617.

6- Hamon, A. B. and M. L. Williams.1984. The soft scale insects of Florida (Homoptera - Coccoidea - Coccidae). In "Arthropods of Florida and Neighboring Land Areas". Florida Dep. Agric. \& Consumer Serv. Div. Plant Industry, II:102105. 
7- Hendawy, A. S. A. 1999. Studies on certain natural enemies of scale insects attacking guava trees at Kafr El-Sheikh Governorate. Ph.D. Thesis, Fac. Agric. Tanta Univ., 145 pp.

8- Moursi, K. S., H. A. Mesbah, A. S. Abo-Shanab and S. I. Abdel-Razak. 2003. Abundance of green shield scale, Chloropulvinaria psidii (Maskell) on some ornamental plants in Alexandria Governorate. J. Adv. Agic. Res., 8(4): 785-792.

9- Quayle, H. J. 1941. Insects of citrus and other subtropical fruits. Ithaca, New York, Comstock Publishing Company, Inc. (Textbook), 583 pp.

10- Radwan, S. G. and N. A. Hassan . 2009. Ecological studies on the green shield scale, Pulvinaria psidii (Mask.) (Hemiptera - Coccidae) infesting mulberry trees in Qalubiya Governorate, Egypt. J. Agric. Sci. Mansoura Univ., 34(2): 1329 - 1338.

11- Reddy, D. B. 1965. Insects, other pests and diseases recorded in the Southeast Asia and Pacific region, mango (Mangifera indica) FAO, Technical Document No. 96:1-16

12- Salama, H. S. and M. R. Saleh. 1970. Distribution of the scale insect, Pulvinaria psidii Mask. (Coccoidea) on orchard trees in relation to environmental factors. Z. ang. Ent., 66 (4):380-385.

13- Shahein, A. A., K. A. A. Hammad, A. SH. Hassan and H. A. Nabil. 2004. Seasonal variation in the population of Pulvinaria psidii Maskell and its associated parasitoid on guava trees at Sharkia Governorate. Egypt. J. Appl. Sci.,19(1): 242-260. 


\section{Pulvinaria psidii (Mask.)دراسات بيئية لحشرة الجوافة القشرية الرخوة}

على أثجار الجوافة بناحية شبين القناطر - محافظة القزلوبيــــة

$$
\begin{aligned}
& \text { السيد عبد الحميد علوان ، عادل محمد سراج ، مها ابراهيم السيد } \\
& \text { معهر بحوث وقابة النباتات - مركز البحوث الزراعية - اللقى - جيزة - مصر }
\end{aligned}
$$

Email: Dr.Sayedelwan@Yahoo.com

تشتهر محافظة القليوبية بزر اعة الجوافة ( 3404 فدان ومعدل الانتاج 7.5 طن/ فدان)

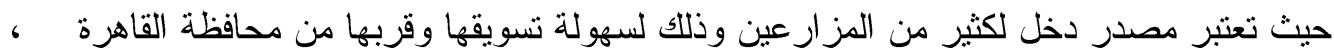
كما ان ثمار الجو افة من الفاكهة الثعبية المحببة لكثير من المو اطنين نظر التو اجدها على مدار العام تقريبا مع انخفاض سعرها مقارنة بأسعار الفاكهة الاخرى. وأثنجار الجوافة من العو ائل المفضلة

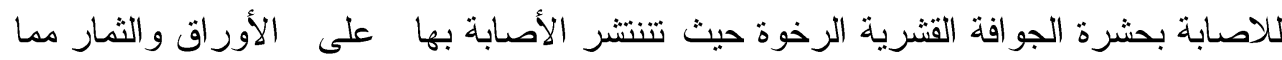
يؤثر على انتاجية الاشجار من الثمار و انخفاض جودنها. أجريت الدراسة الحالية على أشجار جو افة بناحية شبين القناطر بمحافظة القليوبية لمدة عامين متتاليين 2009/2008م بغرض دراسة النشاط الموسمى للحشرة على مدار العام و وعدد الاجيال

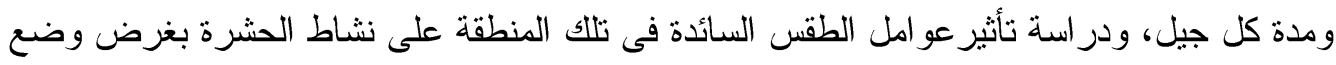
برنامج مكافحة متكامل لها. اتضح من نتائج الدراسة ان حشرة الجو افة القشرية الرخوة تتو اجد على اثجار الجوافة على

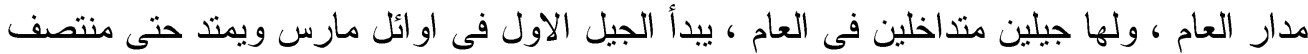
اغسطس وكانت ذروه نشاطه فى منتصف مايو وتز اوحت مدة الجيل من 5.0 - 5.5 شهر وكان متوسط درجة الحرارة و الرطوبة النسبية فى فترة الجيل 20.7 - 21.3مْ ورطوبة نسبية 70.7 -

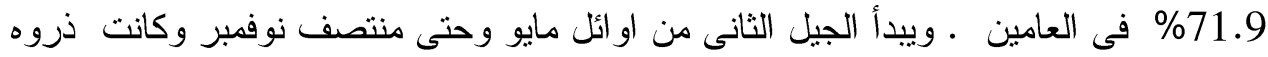

نشاطه فى منتصف اغسطس وتز اوحت مدة الجيل من 6.0- 6.5 شهر وكان منوسط درجة الحرارة والرطوبة النسبية خلال مدة الجيل 24.2 - 25.0مْ ورطوبة نسبية 69.4- 70.4\% فى العامين.

وتبين من الدراسة ان ذروه نشاط الحشرة تكون فى بداية الصيف ونهايته حيث تكون درجة

الحرارة والرطوبة النسبية عالية ، كما اتضح ان تعداد الحشرات الكاملة كان أعلى من تعداد الحوريات فى موسم الثتاء وهذا راجع الى انخفاض درجة الحرارة فى تللك الفترة ووصول اعداد كثيرة من طور الحورية الى طور الحشرة الكاملة التى تقضى فترة الثتاء على قلف الاشجار . اتضح من نتائج التحليل الاحصائى ان درجة الحر ارة و الرطوبة النسبية لهما تأثير معنوى

على نشاط طورى الحورية و الحشرة الكاملة فى كلا الجيلين و على مدار العامين حيث كان مقدار التغير فى تعداد طورى الحورية والحشرة الكاملة الراجع الى تأثثر درجة الحرارة و الرطوبة النسبية

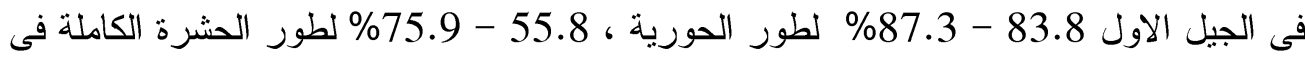
كلا العامين ، وكان مقدار التغير فى الجيل الثانى 55.7 - 69.1\% لطور الحورية ، 51.4 ـ 5 ـ \% 56.6 لطور الحشرة الكاملة فى العامين على التو الى. 